\title{
The Role of Teachers in Promoting Learner Autonomy in Secondary Schools in Saudi Arabia
}

\author{
Saleema M. Alonazi ${ }^{1}$ \\ ${ }^{1}$ College of Education, King Saud University, Riyadh, Saudi Arabia \\ Correspondence: Saleema M. Alonazi, College of Education, King Saud University, Riyadh, Saudi Arabia. \\ E-mail: saleema.alenezi@gmail.com
}

Received: April 1, 2017 Accepted: June 8, 2017 Online Published: June 11, 2017

doi: 10.5539/elt.v10n7p183 URL: http://doi.org/10.5539/elt.v10n7p183

\begin{abstract}
Today, learner autonomy is considered as a desirable goal in language education. The movement towards learner-centered approaches has resulted in more emphasis on the benefits of learner autonomy in the success of language education. The objective of the study was to investigate the roles of the teachers in promoting learner autonomy in Saudi EFL secondary school, with emphasis on the important roles of the facilitator, counselor, resource and manager. A survey questionnaire was used in this study to elicit the responses of 60 EFL teachers in Riyadh during the academic year 2015-2016. The findings of this study revealed that English language teachers often encouraged autonomous learners in their classrooms. They usually implemented different teaching strategies, which demonstrated the four roles: facilitator, counselor, resource and manager. Moreover, the findings showed that teachers were hindered by some difficulties including learners' lack of independent learning skills, rules and regulations applied in schools, and teachers' lack of basic strategies to encourage autonomous learning. Furthermore, the teachers believed that approaches such as teachers' continuous reflection and analysis of their own teaching process, reducing the school rules that restrict the teachers' independence, and offering teachers with professional development programs on learner autonomy can be helpful in developing both learner and teacher autonomy.
\end{abstract}

Keywords: language learning, learner autonomy, teachers' roles

\section{Introduction}

\subsection{Background of the Study}

The shift in second language education has influenced the various ways in which language teaching and learning are conducted and conceived. There has been a gradual shift from traditional approaches to communicative language teaching approach and learner-centered approach. Learner autonomy is considered as one of the major changes accompanied the shift in the second language education "because it emphasizes the role of the learner rather than the role of the teacher" (Jacobs \& Farell, 2003). Thus, the notion of autonomy in language learning is historically and theoretically associated with communicative language teaching (CLT) (Nunan, 2000).

Today, learner autonomy is considered as a desirable goal in language education. Knowles (2001) states that one of the main goals in education is assisting individuals to view learning as a life long process and to learn in a self-directed way. Actually, the movement towards learner-centered approach has resulted in more emphasis on the benefits of learner autonomy in the success of language learning. It is seldom to find independent and autonomous learners in a teacher-centered learning environment (Weimer, 2002). Being autonomous learners is important because the most competent learners are those "who have developed a high degree of autonomy" (Little, 1991).

The concept of learner autonomy has become a popular topic in the modern language education (e.g., Benson, 2001, 2006; Blin, 2004, 2005; Crabbe, 1999; Jimenez Raya, 2009, 2011; Little, 1991, 2007, 2009). Although there are different definitions and descriptions of learner autonomy in the literature, it can be generally defined as the ability to take responsibility of one's own learning. Learner autonomy is sometimes misunderstood in a way that it can be realized without a teacher. In fact, teachers are responsible for developing autonomous learners through their roles and practices in the classroom. Little (1996) states that learners usually do not automatically take responsibility for their learning but they need teachers to help them to do that. Teachers should have other 
roles than just being the source of knowledge to students. By changing their traditional role to the role of an organizer or facilitator, teachers help their students to be more responsible for their own learning.

Teachers' roles in developing autonomous language learning should be taken into account and never be ignored. In the relevant literature, there are many theoretical research articles and books on the roles of language teachers while empirical studies are quite limited (Han, 2014). Additionally, most of the studies on learner autonomy were mainly conducted in universities. Therefore, studies in secondary school contexts deserve much investigation. Although promoting learner autonomy has been considered an educational goal in several contexts, cultural and educational settings greatly effect the way teachers incorporate its principles into their teaching practices (Yıldırım, 2012). Thus, it is imperative to examine the current roles that EFL secondary school teachers play in order to promote learner autonomy in Saudi context.

\subsection{The Statement of the Problem}

Researches on learner autonomy emphasize that learner autonomy is crucial to effective language learning, but at the same time they suggest that intensive support is needed. Autonomy helps learners apply the knowledge and skills acquired in the classroom in real-life situations that may arise outside the classroom. In Saudi learning contexts, English teachers often complain about their learners' learning habits of over-reliance on the teachers. They feel frustrated for the little response they get in return for the efforts they devote to their classes. Thus, fostering learner autonomy seems to be the best solution for both teachers and their learners. Before implementing any interventions that aim at promoting autonomous learning, many areas need to be investigated first. One essential area is to have adequate information about the roles that teachers should adopt in order to encourage learner autonomy.

\subsection{Context of the Study}

In Saudi EFL classes, most of the time, learners seem to have a passive role in their learning (Tamer, 2013). They depend greatly on their teachers and are unwilling to develop a sense of responsibility for the outcome of their learning. This can be attributed to different factors. For a long time, English language in the Kingdom of Saudi Arabia (KSA) has been taught by traditional methods, such as grammar-translation method and an emphasis on rote memory, which are applied in most classrooms. And teachers usually have the authority and decide everything that takes place in the classroom. In addition, most teachers use Arabic, their mother tongue, for several purposes in the classroom (Alharbi, 2015). Instead of learning English as a means of communication, English language continues to be taught as an academic subject (Sofi, 2015). As a result of such teacher-dominated classrooms, students tend to be so reliant on their teachers in English learning.

However, the current education reform in Saudi Arabia has recently developed curricular of different academic subjects including English language. It can be seen that the newly developed English curriculum aims at raising students' engagement, motivation and autonomy. In fact, it emphasizes the promotion of learner autonomy in order to achieve the goal of equipping learners with long life skills that help them cope with the developments of the world (Rahman \& Alhaisoni, 2013). Exploring teachers' practices that aim at fostering learner autonomy could be very useful for curriculum development, materials revision, and teacher training.

\subsection{Significance of the Study}

This study contributes to a better understanding of how teachers' views on learner autonomy are demonstrated in their teaching practices in Saudi EFL context. It also provides empirical support for identifying the challenges that constrain the promotion of autonomy in language classrooms and examines their relation with the notions found in language learning literature.

In Saudi Arabia, very little research has been conducted on teacher and learner autonomy. In his study, (Al Asmari, 2013) investigated the perceptions and practices of university teachers in Taif university regarding learner autonomy. Although his study was done in Saudi Arabia, participants were from different Arab nationalities. Up to date, there is no research that explores the roles of English teachers in Saudi public schools to support students' development of learner autonomy. This study aims to address this gap in the research with the goal of making promoting learner autonomy an appropriate pedagogical goal in Saudi EFL environment.

\subsection{Questions of the Study}

The following are the research questions:

1). What types of role that Saudi EFL secondary school teachers play in order to promote learner autonomy?

2). What are the challenges that Saudi EFL secondary school teachers meet in the promotion of learner autonomy? 
3) What solutions do Saudi EFL secondary school teachers think more helpful in the promotion of learner autonomy?

\section{Literature Review}

\subsection{Learner Autonomy}

Since the 1980s, the concept of learner autonomy has been discussed and argued by many scholars and practitioners. So far, they have failed to reach an agreement on what autonomy really means. Benson (2003) considers the question: 'What is autonomy?' as the most difficult question regarding autonomy in language learning. He justifies it by saying that any answer to this question is likely to be subjective. There are several definitions and interpretations for autonomy in language learning. According to Gardner and Miller (1999), defining the concept of autonomy is difficult because different writers have defined the concept in different ways.

Many definitions of learner autonomy are found in education generally and in language learning particularly. However, the definition of Holec (1981) has been the most cited one in the research of language learning (Benson, 2006). It states that learner autonomy is an "ability to take charge of one's own learning" (Holec, 1981). This definition focuses on 'responsibility' and 'capacity' as main characteristics of learner autonomy. It emphasizes the individuality of learners (Yang, 2005), that the autonomous learners are able of making all the decisions concerning their own learning process.

However, many researchers add or alter this general definition according to their own views. For example, Little (1991, p. 4) refers to autonomy as 'a capacity for detachment, critical reflection, decision making and independent action'. In this definition, Little linked psychology to the nature of learner autonomy. In another example, Benson (2001, p. 47) defines autonomy as the capacity to have control of one's own learning.

Littlewood (1996) describes the autonomous person as one who is able and willing to make and carry out the learning choices independently. He indicates that "this capacity depends on two main components: ability and willingness" (p. 428).

To conclude, with all these different interpretations, autonomy seems to be not only a matter of one's own responsibility for one's learning and it is not provided by an approach or a teacher (Paiva, 2005). It is something much more complex as acknowledged by some researchers such as Benson (1997), Sheerin (1997) Breen and Mann (1997) (cited in Paiva, 2005).

\subsection{The Importance of Autonomy in Language Learning}

At present, it seems that autonomy is gaining an increased interest in different educational fields. Learner autonomy has advantage in helping learners to achieve high degrees of independence and creativity. In language learning, many researchers argue the significance of autonomy from different points of view.

Harmer (2007) suggests that to recompense for the limits of classroom time and to enhance the chances for successful language learning, learners need to be encouraged to develop their own learning strategies so that as far as possible, they become autonomous learners.

Autonomous learners are able to learn from their own successes and failures by strategies that will help them to be more competent learners in the future (Crabbe, 1999). Umeda (2000, cited in Onozawa, 2010) gives three reasons for the importance of autonomy in education; developing a lifelong ability to cope with the rapid social changes, fostering the learner's individuality, and developing the diversity of the learner's educational and cultural background. Benson (2001) indicates that developing such a capacity of taking control over one's own learning is always helpful.

\subsection{Teacher's Roles in Promoting Learner Autonomy}

Because the decision of incorporating autonomy in language learning usually comes from the teacher, autonomy fostering depends essentially on the teachers' redefinition of their own role (Hill, 1994). Crabbe (1999) also proposes that a re-examination of teacher role is needed in helping students to become more autonomous.

As students begin to take more responsibility of their learning, teachers need to play the role of facilitator or counselor (Riley, 1997; Scharle \& Szabo, 2000; Wend en, 2002) (cited in Yang, 2005). Gardner and Miller (1999) indicate that teachers should learn new strategies in order to take on new roles such as counselor, organizer, material developer, evaluator, and manager, etc. Dam (2008) describes teacher role in an autonomous learning environment as a consultant and facilitator. According to Voller (1997), the teacher's roles in promoting autonomous language learning are: facilitator, counselor and resource. 
In reviewing the relevant literature, the following are the most emphasized roles with further explanations.

- Teacher Role as Facilitator:

According to Voller (1997), teacher as facilitator is a commonly used term in the literature on communicative language learning, autonomous language learning, and self-instruction language learning. Dornyei (2001) suggests that if teachers desire to encourage their learners' autonomy, they need to change their role into the role of a facilitator. Chiu (2005) explains that a facilitator of learning is usually considered as a helper who makes learning easier to happen. By serving as a facilitator, teachers make the development more flexible and successful (Yan, 2012). Voller (1997) categorizes the support that a facilitator provides into technical support and psycho-social support.

A facilitator provides the technical support by helping learners to plan and carry out their independent learning by means of needs analysis, objective setting, work planning, and materials selecting. A facilitator provides the psycho-social support by being supportive, helping learners to overcome obstacles, being prepared to enter into a dialogue with learners and raising learners' awareness of the importance of independent learning (Voller, 1997).

- Teacher Role as Counselor:

Teacher as a counselor is another role that is widely used in the discussions of language learning autonomy. A counselor, in general, refers to a person who provides advice to those who need it. Counseling assists learners to talk to someone about their achievements, problems and the ways to solve these problems (Kongchan, 2008). Voller (1997) states that counseling emphasizes on a one-to-one interaction. The role of a counselor is more like a supervisor who help learners to be more self-directed.

Richards and Rodgers (1986, p. 78, cited in Yan, 2012) claim that a teacher-counselor is supposed to be an effective communicator seeking to maximize the leaner engagement through the use of interpretation, confirmation, and feedback. In other words, when a teacher functions as counselor, he/she gives advice and helps learners so that they become more efficient learners. Riley (1997) categorizes the roles of teachers in teaching and counseling as shown in Table 1.

Table 1. Roles in teaching and counseling

\begin{tabular}{ll}
\hline TEACHING & COUNSELING \\
\hline 1. Setting objectives & 1. Eliciting information about aims, needs and wishes \\
2. Determining course content & Why, what for, how, how long: giving information, clarifying \\
3. Selecting materials & 3. Suggesting materials, suggesting other sources \\
4. Deciding on time, place and pace & 4. Suggesting organization procedures \\
5. Deciding on learning tasks & 5. Suggesting methodology \\
6. Managing classroom interaction, initiating & 6. Listening, responding \\
7. Monitoring the learning situation & 7. Interpreting information \\
8. Keeping records, setting homework & 8. Suggesting record-keeping and planning procedures \\
9. Presenting vocabulary and grammar & 9. Presenting materials \\
10. Explaining & 10. Analyzing techniques \\
11. Answering questions & 11. Offering alternative procedures \\
12. Marking, grading & 12. Suggesting self-assessment tools and techniques \\
13. Testing & 13. Giving feedback on self-assessment \\
14. Motivating & 14. Being positive \\
15. Rewarding, punishing & 15. Supporting \\
\hline
\end{tabular}

\section{- Teacher Role as Resource:}

Compared to the teacher roles of facilitator and counselor, the role of resource is less explored in the literature. When the teacher performs as a resource, he/she is perceived as "a source of knowledge and expertise" (Benson \& Voller,1997). In other words, a resource makes his or her knowledge and expertise available to the learners 
whenever it is necessary. Additionally, the teacher as a resource enhances learning conditions to encourage learner autonomy by assisting learners to be aware of a wide range of knowledge resources and learning strategies.

Voller (1997) sees this role similar to the role of a knower with more emphasis on the expertise of the teacher. This teacher role is particularly appropriate for the students how are working independently but still are in need for help from the teacher. Yan (2012) says that the teacher is supposed to be the language resource and should be responsible for providing necessary language input.

The role of the teacher as resource offers interesting possibilities. Teachers become "activity builders, creators of new learning environments." (Ravet \& Layte, 1997). Fostering autonomy implies that learners get appropriate resource material available for use either as individuals or in groups. According to Toyoda (2001), there are three conditions necessary for autonomous learning: accessible and reliable technology, sufficient computer literacy in students, and good communication with and support from peers.

- Teacher Role as Manager and Organizer:

According to Yan (2012), the role of the teacher as manager and organizer is considered as the first and foremost role teacher needs to play in an autonomous leaning setting. In a learner-centered classroom, the teacher should be responsible for organizing different kinds of games and activities such as roleplay, group discussions, presentations and debates. The different activities need to be effective and suitable for the learners' needs and interests. Aiming at developing autonomous learners, teachers are advised to create opportunities for learners to learn spontaneously and creatively and to take their own initiatives to construct their knowledge.

However, it is important that learners know what they are exactly expected to do regarding these activities. Teachers should present clear procedures of the activities and explain the significance of tasks for English learning (Harmer, 2007). So, the students can clearly understand their responsibilities before doing the tasks. When students meet any difficulties, teachers should actively participate in finding solutions.

\subsection{Constraints on Learner Autonomy}

In any given educational context, the challenges that may hinder the promotion of learner autonomy might exist. Paiva (2005) hypothesizes that, in any educational context, elements such as learner, teacher, institution, material, social and political contexts, and technology "can work either for or against autonomy". Huang (2006) explored factors that constraint reflection and autonomy in language learning in a Chinese university. The obstacles identified included factors such as institutional pressures, societal expectations, and conflicts in learner and teacher agendas and priorities in learning.

Investigating EFL teachers' readiness for promoting learner autonomy, Nakata (2011) identified institutional inflexibility and entrance-exam constraints as the major difficulties that hinder Japanese EFL teachers from fostering learner autonomy.

Benson (2000) categorizes the constraints on the promotion of learner autonomy in any learning context into: policy constraints, institutional constraints, conceptions of language, language teaching methodologies (p. 116).

Another important factor that influence teacher's role in the development of learner autonomy is teachers' beliefs and perceptions. Teachers who have traditional views on their role are expected to adopt a teacher-centered approach while those who believe in the idea of student-centered learning are more expected to develop independent learners. There are some studies conducted on teachers' perspectives and beliefs with regards to language learner autonomy (Al Asmari, 2013; Borg \& Al-Busaidi, 2012, Al-Busaidi \& Al-Maamari, 2014; Nguyen, 2014).

To transform the various constraints on autonomy into learning possibilities, the teacher's role is very important. Benson (2000) claims that the teachers should practice a process of mediation between the learners' right to autonomy and the constraints that restrict the use of this right. This way, possibilities of fostering autonomy might exist within constraints. Similarly, Voller (1997), Little (1995) argues that through negotiation, teachers can foster their learners' autonomy despite all the constraints. According to Nunan (1997), teachers can encourage learner autonomy in the language classroom by incorporating reflective lessons into teaching.

However, language teachers may encounter difficulties in creating autonomous learning in classrooms if they are not introduced to the importance of learner autonomy in their initial teacher training. Thanvenius (1999) says that although teachers may be enthusiastic to foster their learners' autonomy, they may still be unaware of what this means for their role. Thus, teacher education should offer teachers with opportunities to experience autonomy-oriented learning to prepare teachers with the ability to support learner's autonomy (Aoki, 2002). The 
following point sheds light on the relationship between teacher autonomy and learner autonomy.

\subsection{Teacher Autonomy}

Teacher autonomy has recently gained more emphasis as a result of the growing attention to the significance of teacher roles in the promotion of autonomy in language learning (Benson, 2001).

According to Little (1995), learner autonomy depends on teacher autonomy in two senses. First, it is unreasonable to expect teachers to foster their learner autonomy if they themselves do not know what makes an autonomous learner. Second, in determining the initiatives they take in their classrooms, teachers have to be able to apply to their teaching those same reflective and self-managing methods that they apply to their learning.

Most importantly, as pointed out by Little (1995), teachers take control of their own teaching process through continuous reflection and analysis. According to Lamb (2008), the teacher learns how to develop autonomously as a professional, through critical reflection.

\section{Method}

\subsection{Research Design}

The researcher has employed a descriptive survey design in this study. Sekaran (2003) indicates that using descriptive research helps the researcher to fully comprehend characteristics of the participants and phenomena. Since this study focuses on the actual roles that English language teachers play in fostering learner autonomy, the descriptive method is appropriate for addressing the research questions and finding the research outcomes.

The research instrument for this study is a questionnaire constructed by the researcher. Items on the questionnaire were constructed from the researcher's knowledge and the literature reviewed on learner autonomy.

\subsection{Population and Sample of the Study}

In the current study, the population consists of secondary school female English language teachers in Riyadh city. The sample is selected randomly. The study sample consists of (60) female EFL teachers - it was easier for the researcher to distribute and collect questionnaires from female schools, as males and females are taught in separate schools in the Saudi educational system. The gender is not taken as a variable in this study.

The participants are secondary school teachers working in Riyadh city in Saudi Arabia during the academic year 2015-2016. They are different in their teaching experiences and educational qualifications.

\subsection{The Instrument of the Study}

The main instrument used for the purpose of data collection is a questionnaire. The questionnaire is distributed among female English language teachers of secondary schools in Riyadh city.

The questionnaire is divided into three sections. The first section consists of 20 items that are related to the roles teachers play in order to encourage autonomy in their educational context. Based on the conducted literature review, the items are decided and organized according to four variables of teachers roles: facilitator, counselor, resource and classroom manager. This section needs the teachers to rate the frequency of their implementation of the included items in their classrooms. Participants are required to answer each item on a five-point Likert scale $(1=$ always, $2=$ often, $3=$ occasionally, $4=$ seldom, $5=$ never $)$.

The second section includes five items on a five-point scale of agreement to identify the constraints on developing learner autonomy. The third section is designed to find out the best ways that teachers find more helpful in promoting learner autonomy in their educational context. It consists of four items arranged in the format of a 5-point Likert scale ranging from strongly agree to strongly disagree (See Appendix A).

The validity of the questionnaire is determined by experts opinions. The questionnaire used in this study was presented to EFL experts in order to judge the affiliation of the questionnaire to its dimensions, its clarity, and suitability to the research objectives. Some of the questionnaire items were modified and others were deleted accordingly.

In order to determine the reliability of the research questionnaire, Cronbach's alpha value was measured. Alpha coefficients of 0.70 or higher are considered acceptable (DeVellis, 1991). The results show that thee overall value of Cronbach's alpha is 0.847 . The values range from 0.809 to 0.834 , which suggest that the items have relatively high degree of reliability. Table 2 presents the Cronbach's alpha values of the three sections of the questionnaire. 
Table 2. Cronbach's alpha values to measure the reliability of the questionnaire

\begin{tabular}{lll}
\hline No & Sections & Cronbach's Alpha \\
\hline 1 & Teachers practices in promoting learner autonomy & 0.834 \\
2 & Challenges teachers face in promoting learner autonomy & 0.816 \\
3 & Approaches that help in promoting learner autonomy & 0.809 \\
& Total & 0.847 \\
\hline
\end{tabular}

\section{Results}

Q 1: What types of role are that Saudi EFL secondary school teachers play in order to promote learner autonomy?

First: the role of "facilitator"

Table 3. The sample responses about their teaching practices for the role "facilitator"

\begin{tabular}{|c|c|c|c|c|c|c|c|c|c|c|c|c|c|c|}
\hline \multirow[t]{3}{*}{$\mathrm{N}$} & \multirow[t]{3}{*}{ Items } & \multirow{2}{*}{\multicolumn{2}{|c|}{ Always }} & \multirow{2}{*}{\multicolumn{2}{|c|}{ Often }} & \multirow{2}{*}{\multicolumn{2}{|c|}{ Occasionally }} & \multirow{2}{*}{\multicolumn{2}{|c|}{ Seldom }} & \multirow{2}{*}{\multicolumn{2}{|c|}{ Never }} & \multirow{3}{*}{$\frac{3}{3}$} & \multirow{3}{*}{$\mathscr{3}$} & \multirow{3}{*}{ 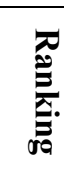 } \\
\hline & & & & & & & & & & & & & & \\
\hline & & $\mathrm{F}$ & $\%$ & $\mathrm{~F}$ & $\%$ & $\mathrm{~F}$ & $\%$ & $\mathrm{~F}$ & $\%$ & $\mathrm{~F}$ & $\%$ & & & \\
\hline 1 & $\begin{array}{l}\text { Helping students to set } \\
\text { up their own learning } \\
\text { objectives. }\end{array}$ & 16 & 26.7 & 13 & 21.7 & 12 & 20.0 & 12 & 20.0 & 7 & 11.7 & 3.32 & 1.37 & 3 \\
\hline 2 & $\begin{array}{l}\text { Helping students to } \\
\text { select their learning } \\
\text { materials. }\end{array}$ & 9 & 15.0 & 15 & 25.0 & 22 & 36.7 & 10 & 16.7 & 4 & 6.7 & 3.25 & 1.11 & 4 \\
\hline 3 & $\begin{array}{l}\text { Helping students to } \\
\text { evaluate their own } \\
\text { learning and progress. }\end{array}$ & 11 & 18.3 & 17 & 28.3 & 19 & 31.7 & 10 & 16.7 & 3 & 5.0 & 3.38 & 1.12 & 2 \\
\hline 4 & $\begin{array}{l}\text { Encouraging students to } \\
\text { reflect on their learning } \\
\text { process. }\end{array}$ & 21 & 35.0 & 18 & 30.0 & 15 & 25.0 & 6 & 10.0 & 0 & 0.0 & 3.90 & 1.00 & 1 \\
\hline & rall mean & & & & & & & & & & & 3.46 & 0.87 & - \\
\hline
\end{tabular}

The four items included in Table 3 are related to the practices of English teachers as being a learning facilitator. The overall mean score is (3.46), which indicates that the respondents often play the role of "facilitator" in order to promote autonomous learning.

- Items that their means represent (often)

The statement no. (4) that has scored the highest mean was "Encouraging students to reflect on their learning process". There were (21) (35\%) teachers who responded "always" to this statement, and (18)(30\%) who responded "often".

- Items that their means represent (occasionally)

There were (11) (18.3\%) teachers who responded "always", and (17)(28.3\%) who responded " often" to item no. (3) "Helping students to evaluate their own learning and progress"; the item "Helping students to set up their own learning objectives" has received (16) answers as "always", and (13) answers as "often"; and (9) teachers responded "always" to the item "Helping students to select their learning materials" whereas (15) teachers responded "often".

Second: the role of "counselor" 
Table 4. The sample responses about their teaching practices for the role "counselor"

\begin{tabular}{|c|c|c|c|c|c|c|c|c|c|c|c|c|c|c|}
\hline \multirow[t]{3}{*}{$\mathrm{N}$} & \multirow[t]{3}{*}{ Items } & \multirow{2}{*}{\multicolumn{2}{|c|}{ Always }} & \multirow{2}{*}{\multicolumn{2}{|c|}{ Often }} & \multirow{2}{*}{\multicolumn{2}{|c|}{ Occasionally }} & \multirow{2}{*}{\multicolumn{2}{|c|}{ Seldom }} & \multirow{2}{*}{\multicolumn{2}{|c|}{ Never }} & \multirow{3}{*}{$\begin{array}{l}3 \\
\mathbb{8} \\
\mathscr{\Xi}\end{array}$} & \multirow{3}{*}{$\mathscr{\theta}$} & \multirow{3}{*}{ 冚 } \\
\hline & & & & & & & & & & & & & & \\
\hline & & $\mathrm{F}$ & $\%$ & $\mathrm{~F}$ & $\%$ & $\mathrm{~F}$ & $\%$ & $\mathrm{~F}$ & $\%$ & $\mathrm{~F}$ & $\%$ & & & \\
\hline 5 & $\begin{array}{l}\text { Making students aware of } \\
\text { the skills and strategies } \\
\text { needed to learn by their } \\
\text { own. }\end{array}$ & 26 & 43.3 & 19 & 31.7 & 11 & 18.3 & 4 & 6.7 & 0 & 0.0 & 4.12 & 0.94 & 3 \\
\hline 6 & $\begin{array}{l}\text { Identifying psychological } \\
\text { problems that inhibit } \\
\text { students' progress. }\end{array}$ & 9 & 15.0 & 16 & 26.7 & 27 & 45.0 & 6 & 10.0 & 2 & 3.3 & 3.40 & 0.98 & 5 \\
\hline 7 & $\begin{array}{l}\text { Making dialogues with } \\
\text { students to find solutions } \\
\text { for their learning } \\
\text { difficulties. }\end{array}$ & 31 & 51.7 & 16 & 26.7 & 8 & 13.3 & 5 & 8.3 & 0 & 0.0 & 4.22 & 0.98 & 2 \\
\hline 8 & $\begin{array}{l}\text { Encouraging students to } \\
\text { make study plans. }\end{array}$ & 19 & 31.7 & 12 & 20.0 & 18 & 30.0 & 6 & 10.0 & 5 & 8.3 & 3.57 & 1.27 & 4 \\
\hline 9 & $\begin{array}{l}\text { Being positive and } \\
\text { supportive especially } \\
\text { when giving feedback }\end{array}$ & 44 & 73.3 & 9 & 15.0 & 5 & 8.3 & 1 & 1.7 & 1 & 1.7 & 4.57 & 0.85 & 1 \\
\hline \multicolumn{2}{|c|}{ Overall mean } & & & & & & & & & & & 3.97 & 0.68 & - \\
\hline
\end{tabular}

With regard to the practices of female English teachers for the role of a counselor, the data of (4) items are shown in table 4. The general mean is (3.97), which suggests that the English teachers often play the role of "counselor" in order to promote learner autonomy.

- Items that their means represent (always)

As shown on Table 4, a high portion of the study participants (44) (73\%) reported that they are always supportive especially when giving feedback while (9) (15\%) selected the answer (often) to this statement.

Regarding the practice of making dialogues with students to find solutions for their learning difficulties, (31) (51.7\%) teachers gave the answer "always" whereas (16) (26.7\%) responded "often".

- Items that their means represent (often)

There were (26) teachers who responded "always", and (19) who responded "often" to the item "Making students aware of the skills and strategies needed to learn by their own". Nineteen teachers expressed "always" for the statement "Encouraging students to make study plans"

- Items that their means represent (occasionally)

As presented in table 4, (27) (45\%) teachers indicated that they occasionally identify psychological problems that inhibit students' progress. Only (9) $(15 \%)$ reported that they always identify learners' psychological problems whereas (16)(26.7\%) reported that they often implement this practice in their classrooms.

Third: The role of "resource" 
Table 5. The sample responses about their teaching practices for the role "resource"

\begin{tabular}{|c|c|c|c|c|c|c|c|c|c|c|c|c|c|c|}
\hline \multirow[t]{3}{*}{$\mathrm{N}$} & \multirow[t]{3}{*}{ Items } & \multirow{2}{*}{\multicolumn{2}{|c|}{ Always }} & & & & & & & & & \multirow{3}{*}{ 赵 } & \multirow{3}{*}{ 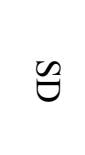 } & \multirow{3}{*}{ 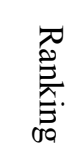 } \\
\hline & & & & \multicolumn{2}{|c|}{ Often } & \multicolumn{2}{|c|}{ Occasionally } & \multicolumn{2}{|c|}{ Seldom } & \multicolumn{2}{|c|}{ Never } & & & \\
\hline & & $\mathrm{F}$ & $\%$ & $\mathrm{~F}$ & $\%$ & $\mathrm{~F}$ & $\%$ & $\mathrm{~F}$ & $\%$ & $\mathrm{~F}$ & $\%$ & & & \\
\hline 10 & $\begin{array}{ll}\text { Suggesting tools } & \text { and } \\
\text { techniques } & \text { for } \\
\text { self-assessment } & \end{array}$ & 17 & 28.3 & 30 & 50.0 & 10 & 16.7 & 1 & 1.7 & 2 & 3.3 & 3.98 & 0.91 & 6 \\
\hline 11 & $\begin{array}{l}\text { Using computer based } \\
\text { learning materials. }\end{array}$ & 35 & 58.3 & 12 & 20.0 & 8 & 13.3 & 5 & 8.3 & 0 & 0.0 & 4.28 & 0.99 & 2 \\
\hline 12 & $\begin{array}{l}\text { Selecting and evaluating } \\
\text { resources according to } \\
\text { students' needs and levels. }\end{array}$ & 35 & 58.3 & 18 & 30.0 & 6 & 10.0 & 1 & 1.7 & 0 & 0.0 & 4.45 & 0.75 & 1 \\
\hline 13 & $\begin{array}{l}\text { Suggesting websites, } \\
\text { videos or online } \\
\text { dictionaries that motivate } \\
\text { students to use the target } \\
\text { language } \\
\text { classroom }\end{array}$ & 34 & 56.7 & 14 & 23.3 & 8 & 13.3 & 2 & 3.3 & 2 & 3.3 & 4.27 & 1.04 & 3 \\
\hline 14 & $\begin{array}{lr}\text { Encouraging } & \text { students to } \\
\text { read English } & \text { books, } \\
\text { magazines } & \text { and } \\
\text { newspapers } & \text { outside } \\
\text { classroom. } & \end{array}$ & 29 & 48.3 & 11 & 18.3 & 15 & 25.0 & 5 & 8.3 & 0 & 0.0 & 4.07 & 1.04 & 5 \\
\hline 15 & $\begin{array}{l}\text { Encouraging students to } \\
\text { study with their peers. }\end{array}$ & 24 & 40.0 & 19 & 31.7 & 15 & 25.0 & 2 & 3.3 & 0 & 0.0 & 4.08 & 0.89 & 4 \\
\hline Ove & all mean & & & & & & & & & & & 4.19 & 0.61 & - \\
\hline
\end{tabular}

Items from 10 to 15 , as shown in table 5, are intended to investigate to what extent the teachers play the role of resource in their educational contexts. The overall mean is (4.19). It suggests that the English teachers are often practice the role of "resource" in order to promote autonomy.

- Items that their means represent (always)

There were (35) (58.3\%) teachers who responded "always", to the statement "Selecting and evaluating resources according to students' needs and levels"; Thirty-five (58.3\%) teachers indicated that they always use computer based learning materials; and (34) (56.7\%) teachers admitted that they always suggest websites, videos or online dictionaries for the students.

- Items that their means represent (often)

Twenty-four (40\%) teachers responded "always" while (19) (31.7\%) responded "often" to the item "Encouraging students to study with their peers". The item, "Encouraging students to read English books, magazines and newspapers outside classroom", has received (29) (48.3\%) responses as "always" and (11) (18.3\%) responses as "often"; and, the item "Suggesting tools and techniques for self-assessment" has received (17) responses of "always" and (30) responses of "often".

Fourth: The role of "Classroom Manager" 
Table 6. The sample responses about their teaching practices for the role "manager"

\begin{tabular}{|c|c|c|c|c|c|c|c|c|c|c|c|c|c|c|}
\hline \multirow[t]{3}{*}{$\mathrm{N}$} & \multirow[t]{3}{*}{ Items } & & & & & & & & & & & \multirow{3}{*}{$\begin{array}{l}3 \\
\mathbb{8} \\
\stackrel{\Xi}{\Xi}\end{array}$} & \multirow{3}{*}{$\Theta$} & \multirow{3}{*}{ 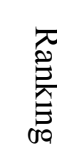 } \\
\hline & & \multicolumn{2}{|c|}{ Always } & \multicolumn{2}{|c|}{ Often } & \multicolumn{2}{|c|}{ Occasionally } & \multicolumn{2}{|c|}{ Seldom } & \multicolumn{2}{|c|}{ Never } & & & \\
\hline & & $\mathrm{F}$ & $\%$ & $\mathrm{~F}$ & $\%$ & $\mathrm{~F}$ & $\%$ & $\mathrm{~F}$ & $\%$ & $\mathrm{~F}$ & $\%$ & & & \\
\hline 16 & $\begin{array}{l}\text { Organizing different kinds } \\
\text { of games and activities in } \\
\text { the classroom. }\end{array}$ & 22 & 36.7 & 16 & 26.7 & 18 & 30.0 & 4 & 6.7 & 0 & 0.0 & 3.93 & 0.97 & 5 \\
\hline 17 & $\begin{array}{l}\text { Providing clear } \\
\text { instructions of the tasks } \\
\text { assigned to students. }\end{array}$ & 38 & 63.3 & 11 & 18.3 & 6 & 10.0 & 3 & 5.0 & 2 & 3.3 & 4.33 & 1.07 & 1 \\
\hline 18 & $\begin{array}{l}\text { Explaining the purposes } \\
\text { and the significance of the } \\
\text { tasks assigned to students. }\end{array}$ & 29 & 48.3 & 17 & 28.3 & 11 & 18.3 & 3 & 5.0 & 0 & 0.0 & 4.20 & 0.92 & 2 \\
\hline 19 & $\begin{array}{l}\text { Giving learners } \\
\text { opportunities to tell their } \\
\text { opinions in the classroom } \\
\text { management. }\end{array}$ & 28 & 46.7 & 16 & 26.7 & 9 & 15.0 & 5 & 8.3 & 2 & 3.3 & 4.05 & 1.13 & 4 \\
\hline 20 & $\begin{array}{l}\text { Giving learners } \\
\text { opportunities to tell their } \\
\text { opinions in their learning } \\
\text { activities }\end{array}$ & 28 & 46.7 & 16 & 26.7 & 12 & 20.0 & 2 & 3.3 & 2 & 3.3 & 4.10 & 1.05 & 3 \\
\hline $\mathrm{Ov}$ & rall mean & & & & & & & & & & & 4.12 & 0.62 & - \\
\hline
\end{tabular}

Table 6 shows the results of five items that are related to the practices of the female English teachers at secondary education for the role of classroom manager. The overall mean is (4.12), it indicates that the English teachers are often playing the role of "classroom manager".

- Items that their means represent (always)

More than half of the teachers (38) selected the answer "always" whereas (11) responded "often" to the item "Providing clear instructions for the tasks assigned to students".

- Items that their means represent (often)

Item no. (18), "Explaining the purposes and the significance of the tasks assigned to students", received (29) responses as "always" and (17) responses as "often" by the study participants. There were (28) teachers who responded "always" and (16) who responded "often" to the statement "Giving learners opportunities to tell their opinions of their learning activities". Twenty-eight teachers expressed "always" and (16) selected "often" to answer statement "Giving learners opportunities to tell their opinions in the classroom management".

Above the results of teachers' practices for each role are presented separately, table 7 shows the extent to which teachers play the four roles in their classrooms with the aim of fostering learner autonomy. 
Table 7. The means and standard deviations of the four roles

\begin{tabular}{lllll}
\hline $\mathrm{N}$ & Roles & Mean & s.deviation & Ranking \\
\hline 1 & Facilitator & 3.46 & 0.87 & 4 \\
2 & Counsellor & 3.97 & 0.68 & 3 \\
3 & Resource & 4.19 & 0.61 & 2 \\
4 & Manager & 4.12 & 0.62 & 1 \\
\multicolumn{2}{l}{ Over all mean } & 3.94 & 0.54 & - \\
\hline
\end{tabular}

The results in Table 7 show that teachers at secondary education often play multiple roles in order to promote learner autonomy. The overall mean of the four roles is 3.94. Ranked from the highest to the lowest are "resource" with a mean of $(0.61 \pm 4.19)$, "classroom manager" with a mean of $(0.62 \pm 4.12)$, "counselor" with a mean of $(0.68$ $\pm 3.97)$, and "facilitator" with a mean of $(0.87 \pm 3.64)$ as the least role that is played by the female English teachers with the aim of encouraging autonomous learners (Figure 1).

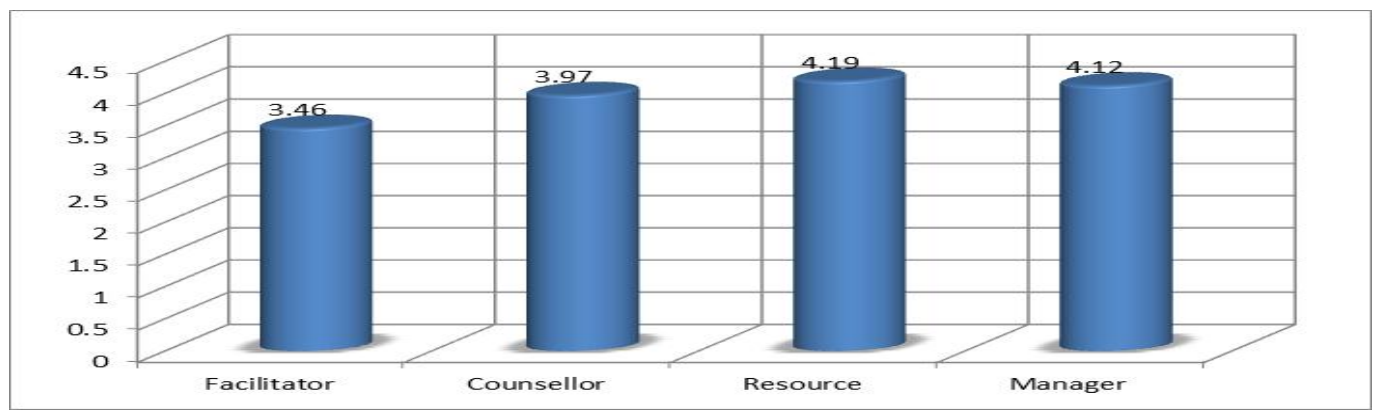

Figure 1. The actual roles that are played by English teachers in order to promote learner autonomy

Q 2: What are the challenges that Saudi EFL secondary school teachers meet in the promotion of learner autonomy?

Table 8. The sample responses about the challenges that the English teachers meet in promoting learner autonomy

\begin{tabular}{|c|c|c|c|c|c|c|c|c|c|c|c|c|c|c|}
\hline \multirow[t]{3}{*}{$\mathrm{N}$} & \multirow[t]{3}{*}{ Items } & \multicolumn{10}{|c|}{ Agreement degree } & \multirow{3}{*}{$\begin{array}{l}\frac{2}{9} \\
\stackrel{3}{=}\end{array}$} & \multirow{3}{*}{ 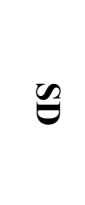 } & \multirow{3}{*}{ 苞 } \\
\hline & & \multicolumn{2}{|c|}{ St.agree } & \multicolumn{2}{|c|}{ Agree } & \multicolumn{2}{|c|}{ Neutral } & \multicolumn{2}{|c|}{ Disagree } & \multicolumn{2}{|c|}{$\begin{array}{l}\text { St. } \\
\text { disagree }\end{array}$} & & & \\
\hline & & $\mathrm{F}$ & $\%$ & $\mathrm{~F}$ & $\%$ & $\mathrm{~F}$ & $\%$ & $\mathrm{~F}$ & $\%$ & $\mathrm{~F}$ & $\%$ & & & \\
\hline 21 & $\begin{array}{l}\text { Students lack the skills } \\
\text { for autonomous learning. }\end{array}$ & 19 & 31.7 & 22 & 36.7 & 15 & 25.0 & 2 & 3.3 & 2 & 3.3 & 3.90 & 1.00 & 1 \\
\hline 22 & $\begin{array}{lcr}\text { Teachers } & \text { lack } & \text { the } \\
\text { essential } & \text { strategies to } \\
\text { promote } & \text { learner } \\
\text { autonomy. } & \end{array}$ & 11 & 18.3 & 18 & 30.0 & 13 & 21.7 & 15 & 25.0 & 3 & 5.0 & 3.32 & 1.19 & 3 \\
\hline 23 & $\begin{array}{l}\text { Teachers themselves are } \\
\text { not autonomous. }\end{array}$ & 14 & 23.3 & 9 & 15.0 & 17 & 28.3 & 15 & 25.0 & 5 & 8.3 & 3.20 & 1.29 & 4 \\
\hline 24 & $\begin{array}{l}\text { Technology is not } \\
\text { effectively implemented } \\
\text { in language learning. }\end{array}$ & 9 & 15.0 & 10 & 16.7 & 12 & 20.0 & 19 & 31.7 & 10 & 16.7 & 2.82 & 1.32 & 5 \\
\hline 25 & $\begin{array}{l}\text { Rules and regulations of } \\
\text { the schools restrict the } \\
\text { teachers' freedom in }\end{array}$ & 27 & 45.0 & 9 & 15.0 & 6 & 10.0 & 9 & 15.0 & 9 & 15.0 & 3.60 & 1.54 & 2 \\
\hline
\end{tabular}


making choices on their

teachings.

Overall mean

$3.37 \quad 0.85$

The constraints to fostering learner autonomy were examined in the second section of the questionnaire. The overall mean of the five items is (3.37), which indicates that there is a neutrality between the agreement and disagreement among the study sample individuals about the constraints that hinder the promotion of learner autonomy.

The study results in table 8 show that the vast majority of the study sample (41) teachers representing (67\%) (31.7\% SA \& 36.7\% A) agreed on item no. (21) "Students lack the skills for autonomous learning"; $60 \%$ of the participants expressed agreement on the item, "Rules and regulations of the schools restrict the teachers' freedom in making choices on their teachings". (27) representing (45\%) teachers responded "strongly agree" and (9) representing (15\%) responded "agree". Approximately 48\% (18.3\% SA \& 30\% A) agreed that teachers lack the essential strategies to promote learner autonomy; (23) teachers representing 38.3\% (23.3\% SA \& $15 \%$ A) indicated that teachers themselves are not autonomous; and (19) teachers representing $(31.7 \%)(15 \%$ SA \& $16.7 \%$ A) showed agreement on that technology is not effectively implemented in language learning.

Q 3: What solutions do Saudi EFL secondary school teachers think more helpful in the promotion of learner autonomy?

Table 9. The sample responses about the approaches that help English teachers to promote learner autonomy

\begin{tabular}{|c|c|c|c|c|c|c|c|c|c|c|c|c|c|c|}
\hline \multirow[t]{3}{*}{$\mathrm{N}$} & \multirow[t]{3}{*}{ Items } & & & & & & & & & & & & & \multirow{3}{*}{ 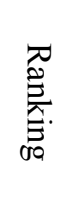 } \\
\hline & & \multicolumn{2}{|c|}{ St.agree } & \multicolumn{2}{|c|}{ Agree } & \multicolumn{2}{|c|}{ Neutral } & \multicolumn{2}{|c|}{ Disagree } & \multicolumn{2}{|c|}{$\begin{array}{l}\text { St. } \\
\text { disagree }\end{array}$} & \multirow[t]{2}{*}{ 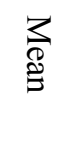 } & \multirow[t]{2}{*}{$\Theta$} & \\
\hline & & $\mathrm{F}$ & $\%$ & $\mathrm{~F}$ & $\%$ & $\mathrm{~F}$ & $\%$ & $\mathrm{~F}$ & $\%$ & $\mathrm{~F}$ & $\%$ & & & \\
\hline 26 & $\begin{array}{lcr}\text { Introducing } & & \text { learner } \\
\text { autonomy in } & \text { teacher } \\
\text { education } & \text { to } & \text { future } \\
\text { teachers. } & & \end{array}$ & 21 & 35.0 & 16 & 26.7 & 18 & 30.0 & 2 & 3.3 & 3 & 5.0 & 3.83 & 1.11 & 4 \\
\hline 27 & $\begin{array}{l}\text { Offering in-service } \\
\text { teachers with professional } \\
\text { development programs on } \\
\text { learner autonomy. }\end{array}$ & 20 & 33.3 & 20 & 33.3 & 14 & 23.3 & 3 & 5.0 & 3 & 5.0 & 3.85 & 1.10 & 3 \\
\hline 28 & $\begin{array}{l}\text { Reducing the institutional } \\
\text { rules that restrict teacher } \\
\text { autonomy. }\end{array}$ & 25 & 41.7 & 20 & 33.3 & 14 & 23.3 & 0 & 0.0 & 1 & 1.7 & 4.13 & 0.89 & 2 \\
\hline 29 & $\begin{array}{l}\text { Teachers' continuous } \\
\text { reflection and analysis of } \\
\text { their own teaching process. }\end{array}$ & 28 & 46.7 & 16 & 26.7 & 15 & 25.0 & 0 & 0.0 & 1 & 1.7 & 4.17 & 0.92 & 1 \\
\hline \multicolumn{2}{|c|}{ Overall mean } & & & & & & & & & & & 4.00 & 0.78 & - \\
\hline
\end{tabular}

The third section of the questionnaire is related to the approaches that help secondary school English teachers in developing autonomous learners. It includes (4) items, their overall mean is (4.0). It indicates that there is an agreement among respondents about the ways that help in developing learner autonomy.

The results indicate that the majority of participants support the statement that teachers' continuous reflection and analysis of their own teaching process can help in developing autonomous learners, (28) (46.7 \%) teachers strongly agreed and (16) (26.7\%) teachers agreed .This statement scored the highest mean (4.17).

The table also shows that most of the respondents agreed on the item no. (28) "Reducing the institutional rules that restrict teacher autonomy". Twenty (33.7\%) participants agreed on the statement and (25) (41.7\%) participants strongly agreed. On the other hand, only $1.7 \%$ participants strongly disagreed. 
Regarding the approach of offering in-service teachers with professional development programs on learner autonomy, the results show that there was an agreement on the statement. There were (20)(33.3\%) teachers who responded "strongly agree", and (20) (33.3\%) who responded "agree".

Finally, Table 9 shows that (21) teachers responded "strongly agree" and (16) responded "agree" to the item "Introducing learner autonomy in teacher education to future teachers".

\section{Discussion}

\subsection{Teacher's Roles in Fostering Learner Autonomy}

With regard to the first objective of the study, the results showed that Saudi English language teachers at secondary schools often play multiple roles in order to promote learner autonomy. Ranked from the highest to the lowest, these roles are resource, classroom manager, counselor, and facilitator. Although teachers' role as a resource scored the highest mean (4.19), the other three roles scored higher than (3.46), which makes no significant difference in the degree of their realizations by teachers. Voller (1997) describes the roles of the language teacher in an autonomous environment as "a facilitator who encourages decision-making processes, a counselor who reacts to the constant needs of learners, and a resource who makes his or her knowledge and expertise available to the learners when it is needed". Camilleri (1997) similarly asserts that in a learner autonomous classroom, a teacher becomes more of a manager, a resource and a counselor.

The results indicated how frequently teachers implement different teaching practices in their classrooms with relation to each role. It was found that female English teachers play the role of facilitator through encouraging the students to reflect on their learning process and helping them evaluate their learning progress. Besides being used in communication, the target language should also be used as a tool for reflection and channel for learning (Little, Ridley, \& Ushioda, 2003). The results also showed that other strategies such as involving students in selecting the objectives and materials for their learning are occasionally implemented. In order to foster learner autonomy successfully, teachers need to shift from being knowledge transmitters to learning facilitators. This requires teachers to involve learners in selecting and modifying both the content and the process of their learning (Nguyen, 2014).

The current study findings revealed that teachers usually play the role of' a counselor through strategies such as being supportive and positive, especially when providing feedback and making dialogues with the students to find solutions for their learning difficulties. This is consistent with what Zhuang (2010) concluded that it is crucial for teachers to establish a smooth and positive relation with students in order to create autonomous environment. Al Asmari (2013) reported that teachers act as a counselor by offering advice to help students manage learning difficulties.

Teachers seem to play the role of resource mostly through selecting and evaluating the resources according to the students' needs, using technology in their educational materials and suggesting websites, videos or online dictionaries that motivate students to use the target language outside the classroom. Undeniably, the new technology has significantly expanded the ways in which teachers can create a motivating learning environment. Describing the role of the teacher as resource, Harmer (2007) says that teachers should be helpful and available, but resist the need to spoon-feed the students. Offering guidance to where students can search for the information is helpful in making them more independent in their learning.

Regarding the role of the teacher as a classroom manager, the majority of teachers indicated that they usually explain the importance of the tasks assigned to the students and provide them with clear instructions for the tasks. Many researchers proposed that learners need to be given opportunities to make decisions regarding their learning setting (Little, 1991; Dam, 1995; Nunan, 1997; Benson, 2001). In this present study, more than $70 \%$ of the surveyed teachers indicated that they give learners opportunities to tell their opinions about their learning activities and classroom management. This result is consistent with the results of Camilleri (1997), and Borg and Al-Busaidi (2012), who found that teachers strongly supported students' involvement in making decisions regarding the classroom management and learning tasks.

\subsection{Challenges Facing Teachers in the Development of Learner Autonomy}

The study sample teachers highlighted constraints that hinder the development of learner autonomy. As agreed by $60 \%$ of the teachers, these constraints include learners' lack of independent learning skills, rules and regulations applied in schools and teachers' lack of the basic strategies to encourage autonomous learning. These findings are consistent with the findings of Borg and Al-Busaidi (2012), where teachers identified factors related to learners, institutions and teachers as obstacles to learner autonomy promotion.

Not all teachers agreed that their students are autonomous learners. This can be attributed to a common 
misconception of learner autonomy that only certain learners can achieve autonomy (Little, 1991). In the current study, $67 \%$ of the teachers indicated that their students are not autonomous language learners. Studies such as (Tanyeli \& Kuter, 2013; Nguyen, 2014), similarly revealed that the teachers did not perceive their students as autonomous learners. Teachers need to know that learner autonomy is not a stable state realized by some learners (Little, 1991), but there are degrees of autonomy (Sinclair, 2000), and that requires support and encouragement from teachers.

The study data also revealed that $60 \%$ of the teachers expressed agreement that schools policy is not supporting their autonomous teaching. There are parallels here with the findings of Huang (2006) and Nakata (2011), who found that institutional pressures and institutional inflexibility were obstacles on learner autonomy.

Another barrier that was indicated by respondents is teachers' lack of the basic skills to foster autonomous learning. This is unparalleled with the current study results of the first question that teachers are actually promoting learner autonomy to a great extent as the mean scored (3.94). It might due to the fact that teachers are not fully understanding the concept of learner autonomy or they are not aware of the types of roles they are performing. (Borg \& Busaidi, 2012; Al Asmari, 2013; Yunus \& Arshad, 2015)

\subsection{Approaches for Helping Teachers in Fostering Learner Autonomy}

Camilleri (1997, p. 32) states "autonomous learning should be supported by autonomous teaching." In order for teachers to practice autonomous teaching, a supportive environment should be created. In the present study, surveyed teachers expressed agreement on the approaches that can contribute to the promotion of learner autonomy.

Approximately $74 \%$ of the teachers agreed that teachers' continuous reflection and analysis of their own teaching process is an effective approach in helping teachers to create autonomous learning. This finding is consistent with the suggestions of other researchers who emphasize the importance of teachers' critical reflection on their practices for taking control of their own teaching process (Little, 1995; Lamb, 2008; Nunan, 1997).

Reducing the rules in schools that restrict the independence of teachers and offering in-service teachers with professional development programs on learner autonomy are other approaches that the study results indicated as important in the development of autonomy. Hirsh (2001) claims that the professional development of teachers is the most effective way in improving the quality of teaching. Khan (2011) similarly suggests that Saudi teachers can always develop themselves by attending some in-service training programs for effective teaching. This result is in line with the results of Al Asmari (2013) and Yunus and Arshad (2015), who concluded that teachers agreed on considering continuous professional development an important futuristic step for improving learner autonomy.

Overall, the data from the present study demonstrated that teachers are currently promoting autonomous language learners to a high degree by taking on different roles: facilitator, counselor, resource and manager. This finding is supported by the findings of several studies in which most of the teachers were positively willing to encourage autonomous learning (Camilleri, 1997; Balçıkanll, 2010; Tok, 2011; Borg \& Albusaidi, 2012; Al Asmari, 2013; Yunus \& Arshad, 2015).

On the other hand, the results were interestingly conflicted with results of the study conducted by Tamer (2013). He investigated the readiness of Saudi university students to take charge of their own learning. The findings indicated that Saudi students are "still being taught in teacher-controlled classrooms where rote learning is the tradition" (p. 72). This could be attributed to factors such as the positive effects of the recently implemented developed curriculum, the professional development programs offered, or as when Borg and Al-Busaidi (2012) suggested that promoting autonomy is easier with beginning language learners than with more proficient learners.

\section{Conclusion}

The present study focused on exploring the roles of English teachers in fostering learner autonomy in secondary education in Saudi Arabia. This was achieved through investigating the actual roles that EFL secondary school teachers play in order to foster autonomous language learning in their educational contexts. The results are suggesting a promising future for learner autonomy in the Saudi Arabian context. The current teachers' practices reflect that there is a remarkable movement toward a more learner-centered pedagogy. So, the present situation might be considered as a transmission period from the traditional approaches to student-centered approaches.

The research findings clarified that the roles of Saudi English teachers in autonomous learning vary according to the contexts they are involved in. In fact, a teacher in such learning is no longer the knowledge provider but also a facilitator, manager, resource and counselor. Also, the results pointed out that having adequate knowledge 
about the concept of learner autonomy and the best strategies that students need to be autonomous learners helps teachers to offer their students with sufficient training to learn independently. Learners, therefore, will be able to manage their language learning in different ways like reflecting on their own learning process, evaluating their performance and making important decisions regarding their learning. Teachers have indispensable role in creating autonomous language learning; and that role should never be undermined.

\section{Recommendations}

Based on the results obtained from this study, the following points are recommended for learner autonomy development in Saudi Arabia:

1) Universities should provide their students' teachers with autonomy-oriented education in term of theories and practices, which guarantee that teachers apply them in their schools.

2) In-service teachers should be exposed to professional development programs such as courses, workshops or seminars on learner autonomy to equip them with the best strategies of fostering autonomy.

3) The Ministry of Education should provide a comprehensive and practical framework of how the concept of learner autonomy should be manifested in language classrooms.

4) The development of autonomous learning needs collaborative work and great efforts from all the parties involved in the educational context including administrations, schools, supervisors, teachers and learners.

\section{References}

Al-Asmari, A. R. (2013). Practices and prospects of learner autonomy: Teachers'perceptions. English Language Teaching Journal, 6(3), 1-10. https://doi.org/10.5539/elt.v6n3p1

Al-Busaidi, S., \& Al-Maamari, M. (2014). Exploring university teachers' understanding of learner autonomy. Theory and Practice in Language Studies, 4(10), 2051-2060. https://doi.org/10.4304/tpls.4.10.2051-2060

Alharbi, H. (2015). Improving students' English speaking proficiency in Saudi public schools. International Journal of Instruction, 8(1), 105-116. https://doi.org/10.12973/iji.2015.818a

Assalahi, H. (2013). Why is the grammar-translation method still alive in the Arab world? teachers' beliefs and its implications for EFL teacher education. TPLS, 3(4). https://doi.org/10.4304/tpls.3.4.589-599

Aoki, N. (2000). Affect and the role of teacher in the development of learner autonomy. In J. Arnold (Ed.), Affect in language learning (pp.142-154). Cambridge: Cambridge University Press.

Balçıkanlı, C. (2010). Learner Autonomy in Language Learning: Student Teachers' Beliefs. Australian Journal of Teacher Education, 35(8), 90-103. http://dx.doi.org/10.14221/ajte.2010v35n1.8

Barfield, A., Ashwell, T., Carroll, M., Collins, K., Cowie, N., Critchley, M., Head, E., Nix, M., Obermeier, A., \& Robertson, M. C. (2001). Exploring and defining teacher autonomy: A collaborative discussion. In A. S.Mackenzie, \& E. McCafferty (Eds.), Developing Autonomy, Proceedings of the College and University Educators, 2001 Conference, Shizuoka, Japan .

Benson, P. (2000). Autonomy as learners' and teachers' right. In B. Sinclair, I. McGrath, \& T. Lamb (Eds.), Learner autonomy, teacher autonomy: Future directions (pp. 111- 117). Essex: Pearson Education Ltd.

Benson, P. (2001). Teaching and Researching Autonomy in Language Learning. London: Longman.

Benson, P. (2003). Learner autonomy in the classroom. Practical English Language Teaching, 1, 289-308. New York, NY: McGraw Hill.

Benson, P. (2006). Autonomy in language teaching and learning. Language Teaching, 40(1), 21-40. http://dx.doi.org/10.1017/S0261444806003958

Benson, P., \& Voller, P. (1997). Autonomy and Independence in Language Learning. London: Longman.

Blin, F. (2004). CALL and the development of learner autonomy: Towards an activity theoretical perspective . ReCALL, 16(2), 377-395. https://doi.org/10.1017/S0958344004000928

Blin, F. (2005). CALL and the development of Learner Autonomy - An activity theoretical study (Unpublished doctoral dissertation). Institute of Educational Technology, The OpenUniversity, Milton Keynes, UK.

Borg, S., \& Al-Busaidi, S. (2012). Teachers' beliefs and practices regarding learner autonomy. ELT Journal Volume, 66(3), 283-292. https://doi.org/10.1093/elt/ccr065

Camilleri, G. (Ed.). (1997). Learner autonomy: The teachers' views. Retrieved from http://archive.ecml.at/documents/pubCamilleriG_E.pdf 
Chiu, C. -Y. (2005). Teacher roles and autonomous language learners: Case study of a cyber English writing course. (Doctoral dissertation, The Pennsylvania State University). Retrieved from https://etda.libraries.psu.edu/paper/6809/

Crabbe, D. (1999. Learner autonomy and the Language Teacher. In C. Ward, \& W. Renandya (Eds.), Language Teaching: New Insights for the Language Teacher. SEAMEO Regional Language Centre. Anthology Series 40, 242-258.

Dam, L. (1995). Learner autonomy3: from theory to classroom practice. Dublin: Authentik

Dam, L. (2008). In-service teacher education for learner autonomy. Independence, 43, 21-28.

DeVellis, R. F. (1991). Scale development: Theory and applications. Newbury Park, Calif: Sage.

Dörnyei, Z. (2001). Motivational strategies in the language classroom. Cambridge: Cambridge University Press. Cambridge Books Online. https://doi.org/10.1017/CBO9780511667343

Dornyei, Z. (2003). Questionnaires in second language research: Construction, administration, and processing. Mahwah, NJ: Lawrence Erlbaum associates, Publishers.

Gardner, D., \& Miller, L. (1999). Establishing self-access: from theory to practice. Cambridge: Cam bridge University Press.

Han, L. (2014). Teacher's role in developing learner autonomy: A Literature review. International Journal of English Language Teaching, 1(2), 21-27. https://doi.org/10.5430/ijelt.v1n2p21

Harmer, J. (2007). The Practice of English language teaching (4th ed.) London: Pearson Education. https://doi.org/10.1093/elt/ccn029

Hill, B. (1994). Self-managed learning: State of the art. Language Teaching, 27, 213-23. https://doi.org/10.1017/S0261444800000185

Hirsh, S. (2001). We're growing and changing. Journal of Staff Development, 22(3), 255-258.

Holec, H. (1981). Autonomy and foreign language learning. London: Pergamon Press.

Huang, J. (2006). Learner resistance in metacognition training? An exploration of mismatches between learner and teacher agendas. Language Teaching Research, 10(1), 95-117. https://doi.org/10.1177/136216880601000107

Jacobs, G. M., \& Farrell, T. S. (2001). Paradigm shift: Understanding and implementing change in second language education. Teaching English as a second or foreign language.

Jimenez Raya, M. (2009). Teacher education for learner autonomy: An analysis of the EuroPAL contribution to a knowledge base. Innovation in Language Learning and Teaching, 3(3), 221-238. https://doi.org/10.1080/17501220903404459

Jimenez Raya, M. (2011). Enhancing pedagogy for autonomy: The potential of a case-based approach in promoting reflection and action. Innovation in Language Learning and Teaching, 5(2), 151-163. https://doi.org/10.1080/17501229.2011.577531

Khan, I. A. (2011). Learning difficulties in English: Diagnosis and pedagogy in Saudi Arabia. Educational Research, 2(7), 1248-1257.

Kongchan, C. (2008). Using learning profiles to inspire effective consultations. rEFLections, 4,15-30.

Lamb, T. E. (2008). Learner and teacher autonomy: synthesizing an agenda. In T. E. Lamb, \& H. Reinders (Eds.), Learner and teacher autonomy: concepts, realities and responses (pp. 269-284). Amsterdam, John Benjamins. https://doi.org/10.1075/aals.1

Little, D. (1991). Learner Autonomy: definitions, issues and problems. Dublin: Authentik.

Little, D. (1995). Learning as dialogue: The dependence of learner autonomy on teacher autonomy. System, 23(2), 175-182. http://dx.doi.org/10.1016/0346-251X(95)00006-6

Little, D. (1996). Freedom to learn and compulsion to interact: Promoting learner autonomy through the use of information systems and information technologies. In R. Pemberton, E. Li, W. Or, \& H. Pierson (Eds.), Taking Control: Autonomy in Language Learning (pp. 203-218). Hong Kong University Press.

Little, D. (2007). Language learning autonomy: Some Fundamental Considerations Revisited. Innovation in Language Learning and Teaching, 1(1), 14-29. https://doi.org/10.2167/illt040.0 
Little, D. (2009). Language learner autonomy and the European Language portfolio: Two L2 English examples. Language Teaching, 42, 222-233. https://doi.org/10.1017/S0261444808005636

Little, D., Ridley, J., \& Ushioda, E. (Eds.). (2003). Learner autonomy in the foreign language classroom: Teacher, learner, curriculum and assessment. Dublin: Authentik.

Littlewood, W. (1996). "Autonomy": An anatomy and a framework. System, 24(4), 427-435. https://doi.org/10.1016/S0346-251X(96)00039-5

Nakata, Y. (2011). Teachers' readiness for promoting learner autonomy: A study of Japanese EFL high school teachers. Teaching and Teacher Education, 27(5), 900-910. https://doi.org/10.1016/j.tate.2011.03.001

Nguyen, T. N. (2014). Learner autonomy in language learning: Teachers' beliefs (Unpublished doctoral dissertation). Queensland University of Technology, Australia.

Nunan, D. (1997). Designing and adapting materials to encourage learner autonomy. In P. Benson, \& P. Voller (Eds.), Autonomy and independence in language learning (pp. 192-203). London: Longman.

Onozawa, C. (2010). Promoting autonomy in the language class: How autonomy can be applied in the language class? Retrieved from www.kyoai.ac.jp/college/ronshuu/no-10/onozawa1.pdf

Paiva, V. L. M. O. (2005). Autonomy in second language acquisition. In SHARE: An electronic magazine by Omar Villarreal and Marina Kirac, (146) 6.

Rahman, M. M., \& Alhaisoni, E. (2013). Teaching English in Saudi Arabia: Prospects and challenges. Academic Research International, 4(1), 112-118.

Ravet, S., \& Layte, M. (1997). Technology -based training: A comprehensive guide to choosing, implementing, managing and developing new technologies in training. London: Kogan Page.

Riley, P. (1997). The guru and the conjurer: aspects of counselling for self- access. In P. Benson, \& P. Voller (Eds.), Autonomy and independence in language learning (pp. 114-131).New York: Longman.

Sekaran, U. (2003). Research methods for business (4th ed.). Hoboken, NJ: John Wiley \& Sons.

Sinclair, B. (2000). Learner autonomy: the next phrase? In B. Sinclair, I. McGrath, \& T. Lamb (Eds.), Learner Autonomy, Teacher Autonomy: Future Directions. Addison Wesley: Longman.

Sofi, L. (2015). Teaching English in Saudi Arabia Through the Use of Multimedia (Unpublished Master Theses). University of San Francisco, USA.

Tamer, O. (2013). A Dissertation on students' readiness for autonomous learning of English as a foreign language (Unpublished Master Theses). University of Sunderland, England

Tanyeli, N., \& Kuter, S. (2013). Examining learner autonomy in foreign language learning and instruction. Egitim Arastirmalari-Eurasian Journal of Educational Research, 53/A, 19-36.

Thavenius, C. (1999). Teacher autonomy for learner autonomy. In S. Cotterall, \& D.Crabbe (Eds.). Learner autonomy in language learning: Defining the field and effecting change (pp. 159-164). Frankfurt: Peter Lang.

Tok, H. (2011). Classroom instructional responsibilities and learner autonomy: A case study in Turkey. Energy Education Science and Technology Part B: Social and Educational Studies, 3(3), 211-220.

Toyoda, E. (2001). Exercise of learner autonomy in project-oriented CALL. CALL-EJ Online, 2(2).

Voller, P. (1997). Does the teacher have a role in autonomous language learning. In P. Benson, \& P. Voller (Eds.), Autonomy and independence in language learning (pp. 98-113). London: Longman.

Weimer, M. (2002). Learner-Centred teaching. San Francisco: Jossey Bass. A Wiley Company.

Yan, S. (2012). Teacher's roles in autonomous learning. Journal of Sociological Research, 3(2), 557-562. https://doi.org/10.5296/jsr.v3i2.2860

Yang, T. (2005). An overview of learner autonomy: Definitions, misconceptions, and identifications: Retrieved from http://repo.lib.ryukoku.ac.jp/jspui/bitstream/10519/2654/1/KJ00004466208.p df

Yildırım, O. (2012). A Study on a group of Indian English as a second language learners' perceptions of autonomous learning. Turkish Online Journal of Qualitative Inquiry, 3(2), 18-29.

Yunus, M., \& Arshad, N. D. ( 2015). ESL teachers' perceptions toward the practices and prospects of autonomous language learning. Asian Social Science, 11(2), 41-51. 
Zhuang, J. (2010). The changing role of teachers in the development of learner autonomy. Journal of Language Teaching and Research, 1(5), 591-595. https://doi.org/10.4304/j1tr.1.5.591-595

\section{Appendix A}

\section{The Role of Teachers in Promoting Learner Autonomy in Secondary Schools in Saudi Arabia}

Dear Teacher,

The purpose of this questionnaire is to explore EFL secondary school teachers' roles in promoting learner autonomy.

There is no correct or incorrect answer; we are merely interested in your real and honest responses. All responses to this questionnaire are completely anonymous and will be used for research purpose only.

1-: How frequently do you implement the following practises in your classroom?

\begin{tabular}{|c|c|c|c|c|c|c|}
\hline No. & & $\begin{array}{l}\text { Always } \\
\text { (1) }\end{array}$ & $\begin{array}{l}\text { Often } \\
\text { (2) }\end{array}$ & $\begin{array}{l}\text { Occasionally } \\
\text { (3) }\end{array}$ & $\begin{array}{l}\text { Seldom } \\
\text { (4) }\end{array}$ & $\begin{array}{l}\text { Never } \\
(5)\end{array}$ \\
\hline 1. & $\begin{array}{l}\text { Helping students to set up their own } \\
\text { learning objectives. }\end{array}$ & 0 & 0 & 0 & 0 & 0 \\
\hline 2. & $\begin{array}{l}\text { Helping students to select their learning } \\
\text { materials. }\end{array}$ & 0 & 0 & 0 & 0 & o \\
\hline 3. & $\begin{array}{l}\text { Helping students to evaluate their own } \\
\text { learning and progress. }\end{array}$ & 0 & 0 & 0 & 0 & o \\
\hline 4. & $\begin{array}{l}\text { Encouraging students to reflect on their } \\
\text { learning process. }\end{array}$ & 0 & 0 & 0 & 0 & ○ \\
\hline 5. & $\begin{array}{l}\text { Making students aware of the skills and } \\
\text { strategies needed to learn by their own. }\end{array}$ & 0 & 0 & 0 & 0 & o \\
\hline 6. & $\begin{array}{l}\text { Identifying psychological problems that } \\
\text { inhibit students' progress. }\end{array}$ & 0 & 0 & 0 & 0 & o \\
\hline 7. & $\begin{array}{l}\text { Making dialogues with students to find } \\
\text { solutions for their learning difficulties. }\end{array}$ & 0 & 0 & 0 & $\circ$ & o \\
\hline 8. & $\begin{array}{l}\text { Encouraging students to make study } \\
\text { plans. }\end{array}$ & $\circ$ & 0 & 0 & 0 & o \\
\hline 9. & $\begin{array}{l}\text { Being positive and supportive especially } \\
\text { when giving feedback }\end{array}$ & 0 & 0 & 0 & 0 & o \\
\hline 10. & $\begin{array}{l}\text { Suggesting tools and techniques for } \\
\text { self-assessment }\end{array}$ & 0 & 0 & 0 & 0 & ○ \\
\hline 11. & $\begin{array}{l}\text { Using computer based learning } \\
\text { materials. }\end{array}$ & 0 & 0 & 0 & 0 & $\circ$ \\
\hline 12. & $\begin{array}{l}\text { Selecting and evaluating resources } \\
\text { according to students' needs and levels. }\end{array}$ & $\circ$ & 0 & 0 & $\circ$ & 0 \\
\hline
\end{tabular}




\begin{tabular}{|c|c|c|c|c|c|c|}
\hline 13. & $\begin{array}{l}\text { Suggesting websites, videos or online } \\
\text { dictionaries that motivate students to use } \\
\text { the target language outside classroom }\end{array}$ & 0 & 0 & O & O & 0 \\
\hline 14. & $\begin{array}{l}\text { Encouraging students to read English } \\
\text { books, magazines and newspapers } \\
\text { outside classroom. }\end{array}$ & 0 & 0 & 0 & 0 & 0 \\
\hline 15. & $\begin{array}{l}\text { Encouraging students to study with their } \\
\text { peers. }\end{array}$ & 0 & 0 & 0 & 0 & 0 \\
\hline 16. & $\begin{array}{l}\text { Organizing different kinds of games and } \\
\text { activities in the classroom. }\end{array}$ & 0 & 0 & 0 & 0 & 0 \\
\hline 17. & $\begin{array}{l}\text { Providing clear instructions of the tasks } \\
\text { assigned to students. }\end{array}$ & 0 & 0 & 0 & 0 & 0 \\
\hline 18. & $\begin{array}{l}\text { Explaining the purposes and the } \\
\text { significance of the tasks assigned to } \\
\text { students. }\end{array}$ & 0 & 0 & 0 & 0 & 0 \\
\hline 19. & $\begin{array}{l}\text { Giving learners opportunities to tell } \\
\text { their opinions in the classroom } \\
\text { management. }\end{array}$ & 0 & 0 & 0 & 0 & 0 \\
\hline 20. & $\begin{array}{l}\text { Giving learners opportunities to tell } \\
\text { their opinions in their learning activities }\end{array}$ & 0 & 0 & 0 & 0 & 0 \\
\hline
\end{tabular}

2-: The constraints that hinder the development of learner autonomy are:

\begin{tabular}{|c|c|c|c|c|c|c|}
\hline No. & & $\begin{array}{l}\text { Strongly } \\
\text { agree } \\
\text { (1) }\end{array}$ & $\begin{array}{l}\text { Agree } \\
(2)\end{array}$ & $\begin{array}{l}\text { Neutral } \\
\text { (3) }\end{array}$ & $\begin{array}{l}\text { Disagree } \\
\text { (4) }\end{array}$ & $\begin{array}{l}\text { Strongly } \\
\text { disagree } \\
\text { (5) }\end{array}$ \\
\hline 21. & $\begin{array}{l}\text { Students lack the skills for autonomous } \\
\text { learning. }\end{array}$ & ○ & ○ & $\circ$ & ○ & O \\
\hline 22. & $\begin{array}{l}\text { Teachers lack the essential strategies to } \\
\text { promote learner autonomy. }\end{array}$ & $\circ$ & ○ & ○ & O & O \\
\hline 23. & Teachers themselves are not autonomous. & O & o & o & O & O \\
\hline 24. & $\begin{array}{l}\text { Technology is not effectively } \\
\text { implemented in language learning. }\end{array}$ & ○ & ○ & o & o & o \\
\hline 25. & $\begin{array}{l}\text { Rules and regulations of the schools } \\
\text { restrict the teachers' freedom in making } \\
\text { choices on their teachings. }\end{array}$ & O & o & o & o & O \\
\hline
\end{tabular}


3-: The approaches that help teachers in promoting learner autonomy are:

\begin{tabular}{|c|c|c|c|c|c|c|}
\hline No. & & $\begin{array}{l}\text { Strongly } \\
\text { agree } \\
\text { (1) }\end{array}$ & $\begin{array}{l}\text { Agree } \\
(2)\end{array}$ & $\begin{array}{l}\text { Neutral } \\
\text { (3) }\end{array}$ & $\begin{array}{l}\text { Disagree } \\
\text { (4) }\end{array}$ & $\begin{array}{l}\text { Strongly } \\
\text { disagree } \\
\text { (5) }\end{array}$ \\
\hline 26 & $\begin{array}{l}\text { Introducing learner autonomy in } \\
\text { teacher education to future teachers. }\end{array}$ & O & 0 & 0 & 0 & 0 \\
\hline 27 & $\begin{array}{l}\text { Offering in-service teachers with } \\
\text { professional development programs } \\
\text { on learner autonomy. }\end{array}$ & O & 0 & 0 & 0 & 0 \\
\hline 28 & $\begin{array}{l}\text { Reducing the institutional rules that } \\
\text { restrict teacher autonomy. }\end{array}$ & 0 & 0 & 0 & 0 & 0 \\
\hline 29 & $\begin{array}{l}\text { Teachers' continuous reflection and } \\
\text { analysis of their own teaching } \\
\text { process. }\end{array}$ & 0 & 0 & 0 & 0 & 0 \\
\hline
\end{tabular}

\section{Copyrights}

Copyright for this article is retained by the author(s), with first publication rights granted to the journal.

This is an open-access article distributed under the terms and conditions of the Creative Commons Attribution license (http://creativecommons.org/licenses/by/4.0/). 